\title{
Dependence of Highly Enriched Human Bone Marrow Progenitors on Hemopoietic Growth Factors and Their Response to Recombinant Erythropoietin
}

\author{
Colin A. Sieff, Stephen G. Emerson, Allan Mufson, Thomas G. Gesner, and David G. Nathan \\ Division of Hematology and Oncology, The Childrens Hospital and Dana-Farber Cancer Institute; \\ Division of Hematology, Brigham \& Women's Hospital, and Departments of Pediatrics and Medicine, Harvard Medical School, Boston, \\ Massachusetts 02115; and Genetics Institute, Cambridge, Massachusetts 02140
}

\begin{abstract}
Human bone marrow cells were sequentially fractionated by three negative selection steps to remove adherent cells and Fc receptorbearing cells, followed by immune adsorption (panning) to deplete maturing cells that react with a panel of monoclonal antibodies. This nonadherent $F c$ receptor and antibody negative fraction could be further enriched by a positive selection "panning" step, using an antibody to HLA-DR antigen; 12-27\% of the cells formed erythroid burst-forming unit (BFU-E), erythroid colonyforming unit, granulocyte-monocyte colony-forming unit, and erythroid and granulocyte and/or monocyte colony-forming unitderived colonies with recovery of $0.5-1 \%$ of the cells and 20 $100 \%$ of the colony-forming cells.

Sequential fractionation resulted in increasing dependence of a subset of BFU-E-derived colonies on exogenous burst-promoting activity (BPA) for proliferation in culture, but the most enriched progenitor fraction still contained a proportion of accessory cell or BPA-independent BFU-E that responded to either natural or biosynthetic erythropoietin when added to cultures on day 0 in the absence of BPA. If the addition of erythropoietin was delayed until day 3 , the data suggest that this population of BFU-E either died or became unresponsive to erythropoietin. Delayed addition of erythropoietin to cultures of enriched progenitors provided a sensitive BPA assay, since BPA-independent but erythropoietin-responsive BFU-E were eliminated. The surviving BFU-E that were dependent for their proliferation on the presence of both BPA and erythropoietin showed a characteristic dose response to increasing BPA concentrations.
\end{abstract}

\section{Introduction}

Hemopoietic progenitors depend on specific glycoprotein growth factors for their survival, proliferation, and terminal differentiation in vitro. Insight into the regulation of hemopoiesis at a cellular level requires purification of both progenitors and hemopoietic growth factors (HGFs). ${ }^{1}$ To date, at least three human

Address correspondence to Dr. Sieff, Room 1630, Dana-Farber Cancer Institute, 44 Binney St., Boston, MA 02115.

Received for publication 16 July 1985.

1. Abbreviations used in this paper: $\mathrm{Ab}^{-}$and $\mathrm{Ab}^{+}$, cells without and with antigens recognized by a panel of monoclonal antibodies, respectively; $\mathrm{Ad}^{-}$and $\mathrm{Ad}^{+}$, plastic nonadherent and adherent cells, respectively; BFUE, erythroid burst-forming unit; BPA, burst-promoting activity; CFU$\mathrm{E}$, erythroid colony-forming unit; CFU-GM, granulocyte-monocyte CFU; CFU-MIX, erythroid and granulocyte and/or monocyte CFU; CM, con-

J. Clin. Invest.

(C) The American Society for Clinical Investigation, Inc. 0021-9738/86/01/0074/08 \$1.00

Volume 77, January 1986, 74-81
HGFs have been purified to homogeneity and their genes cloned (1-5): Granulocyte-macrophage colony-stimulating factor (GMCSF) stimulates the formation of colonies derived from granulocyte and/or monocyte progenitors (CFU-GM). We have recently demonstrated (6) that purified recombinant GM-CSF also has burst-promoting activity (BPA) for erythroid burst-forming units (BFU-E) and stimulates the formation of colonies derived from multipotent progenitors (CFU-MIX); erythroid-potentiating activity (EPA) $(2,3)$ increases BFU-E and erythroid colonyforming unit (CFU-E) numbers above background in a low serum assay; and erythropoietin (EP) $(4,5)$ acts on committed erythroid progenitors and is essential for the terminal maturation of erythroid cells.

Progenitor purification is necessary because accessory "helper" cells present in unfractionated bone marrow produce factors that result in significant background noise in colonyforming assays for growth factor activity. Progenitors comprise $<1 \%$ (usually $<0.5 \%$ ) of human bone marrow cells. Because of the heterogeneity of bone marrow tissue, attempts to purify them using physical parameters have been only partially successful $(7,8)$, although murine CFU-E have been greatly enriched (9). Monoclonal antibodies and/or lectins have been used with more success for purifying mouse (10) and human (11-14) progenitors using negative and/or positive selection by complement lysis $(13,14)$, immune rosetting (14), or fluorescence-activated cell sorting (FACS) $(10,11,13)$ techniques. While significant enrichment using these methods has been obtained, disadvantages include nonspecific cell loss with poor progenitor recovery, and long sorting times with the FACS that make difficult the selection of these rare cells in sufficient numbers for further study. Immunoadsorption to plastic dishes (panning) combined with the FACS has been used to partially enrich for murine bone marrow progenitors (15), and recently we have shown that the progenitors present in human fetal liver can be greatly enriched with excellent recovery using immunoadsorption to immunoglobulin-coated plates (16).

In this report, we show that sequential fractionation of human bone marrow cells results in increasing dependence of BFU-E on an exogenous source of BPA for proliferation in culture. Panning, using negative selection with a combination of monoclonal antibodies, followed by positive selection with an antibody

ditioned medium; $\mathrm{DR}^{+}$and $\mathrm{DR}^{-}$, cells expressing or not expressing HLADR antigens, respectively; EP, erythropoietin; EPA, erythroid-potentiating activity; FACS, fluorescence-activated cell sorting; $\mathrm{Fcr}^{-}$and $\mathrm{Fcr}^{+}$, cells without and with receptors for the Fc portion of immunoglobulins, respectively; FCS, fetal calf serum; GCT, giant cell tumor; GCT-CM, GCT cell line-conditioned medium; GM-CSF, granulocyte-monocyte colony-stimulating factor; HGF, hemopoietic growth factor; IMDM, Iscove's modified Dulbecco's medium; Mo-CM, Mo T lymphoblast cell line-conditioned medium; REC, recombinant EP; U, unfractionated Ficoll-Hypaque bone marrow mononuclear cells. 
to HLA-DR antigens, can greatly enrich for progenitor cells with good recovery. Among these progenitors are two distinct BFUE populations. One subset is initiated into terminal differentiation by EP alone; the second and somewhat larger subset requires both BPA and EP to differentiate. (Indeed, this class of BFU-E cannot survive $3 \mathrm{~d}$ in culture if BPA is withheld.) Manipulation of these subsets by delayed addition of either partially purified human urinary or recombinant erythropoietin (REC) to enriched progenitors thereby provides a method to perform a sensitive BPA assay with no or minimal background colony formation.

\section{Methods}

Bone marrow samples. Normal human bone marrow was obtained by aspiration from adult volunteers. Approximately 5-15 $\mathrm{ml}$ from 1 to 2 aspirations was collected into sterile syringes containing preservativefree heparin.

Cell separation procedures. The marrow suspensions were separated over Ficoll-Hypaque $(1.077 \mathrm{~g} / \mathrm{cu} \mathrm{cm})$ (Pharmacia Fine Chemicals, Piscataway, $\mathrm{NJ}$ ) at $400 \mathrm{~g}$ for $40 \mathrm{~min}$ at $20^{\circ} \mathrm{C}$ and the interface mononuclear cells collected, washed three times, and resuspended in Iscove's modified Dulbecco's medium (IMDM) containing 20\% fetal calf serum (FCS). The cells were incubated in 100-mm tissue culture dishes (Lux, Miles Laboratories, Naperville, IL) overnight at $37^{\circ} \mathrm{C}$ and the nonadherent cells $\left(\mathrm{Ad}^{-}\right)$removed with two gentle washes and centrifuged.

Fc receptor-positive cell depletion. In some experiments, the $\mathrm{Ad}^{-}$cells were resuspended in phosphate-buffered saline (PBS) containing 5\% FCS and incubated on immunoglobulin-coated $100-\mathrm{mm}$ plastic Petri dishes for $1 \mathrm{~h}$ at $4^{\circ} \mathrm{C}$. $\mathrm{Fc}$ receptor negative $\left(\mathrm{Fcr}^{-}\right)$cells were removed with two gentle washes and the cells centrifuged.

Immunoadsorption to immunoglobulin-coated plates (panning). The bone marrow cells were incubated at $4^{\circ} \mathrm{C}$ for $30 \mathrm{~min}$ with previously determined optimal concentrations of either Leu 1 and 5 b (BectonDickinson Monoclonal Centre Inc., Mountain View, CA) to label T lymphocytes or a panel of 10-12 monoclonal antibodies directed against myeloid, erythroid, and lymphoid maturation antigens (Table I). The cells were washed twice in IMDM containing $2 \%$ FCS and once in PBS/ $5 \% \mathrm{FCS}$, resuspended at $5-6 \times 10^{6} / \mathrm{ml}$ in PBS/5\% FCS, and $4-5-\mathrm{ml}$ aliquots were incubated at $4^{\circ} \mathrm{C}$ for $1 \mathrm{~h}$ on $100-\mathrm{mm}$ plastic bacteriological petri dishes (Fisher Scientific Co., Pittsburgh, PA) that had been previously coated with rabbit anti-mouse immunoglobulin (see below). The nonadherent cells ( $\mathrm{T}^{-}$[Leu 1/5b]) or antibody-negative cells ( $\mathrm{Ab}^{-}$[multiple antibodies]) were removed and washed twice by gently swirling, tilting, and decanting, and then a second incubation on another antibody-coated plate was carried out to ensure removal of all antibody labeled cells. In some experiments, the $\mathrm{Ab}^{-}$cells were incubated with a monoclonal antibody to HLA-DR antigen (Becton-Dickinson \& Co., clone L243), washed, and incubated at $4^{\circ} \mathrm{C}$ for $1 \mathrm{~h}$ on a third immunoglobulin-coated plate. Nonadherent HLA-DR-negative cells were removed with two gentle washes. The plates were then washed three times and the adherent HLA-DR-positive cells were removed by vigorous pipetting using $10 \mathrm{ml}$ of IMDM $/ 2 \%$ FCS. Most of the adherent cells detached with this procedure, but occasionally it was necessary to remove the remaining cells with a rubber policeman. Cytocentrifuge preparations of the different cell fractions were stained with Wright-Giemsa for differential counting.

Preparation of immunoglobulin-coated plates. Panning was carried out by minor modifications of the method of Wysocki and Sato (21). $100 \times 15-\mathrm{mm}$ polystyrene bacteriological petri dishes (Fisher Scientific Co.) (catalogue 8-751-12) were incubated at room temperature in $10 \mathrm{ml}$ affinity-purified rabbit anti-mouse IgG, and $A \& M$ heavy and light chain immunoglobulin (Zymed Laboratories Inc., San Francisco, CA) diluted to $10 \mu \mathrm{g} / \mathrm{ml}$ in PBS. After $40 \mathrm{~min}$, the plates were washed three times in PBS and then incubated at $4^{\circ} \mathrm{C}$ in $5 \mathrm{ml} \mathrm{PBS} / 1 \%$ FCS until required.

Culture procedures. The bone marrow cells were cultured in a mixture containing $30 \%$ FCS, $1 \%$ bovine serum albumin (BSA) (Sigma Chemical Co., St. Louis, MO), $10^{-4} \mathrm{M}$ mercaptoethanol (Sigma Chemical Co.), penicillin/streptomycin, and $0.9 \%$ methyl cellulose. Mo T lymphoblast
Table I. Monoclonal Antibodies Used to Fractionate Bone Marrow

\begin{tabular}{llc}
\hline Antibody & Specificity & Source and reference \\
\hline Leu 1 & T lymphocyte & $\begin{array}{c}\text { Becton-Dickinson } \\
\text { \& Co. }\end{array}$ \\
Leu 5b & T lymphocyte, some & $\begin{array}{c}\text { Becton-Dickinson } \\
\text { \& Co. }\end{array}$ \\
Leu 9 & NK cells & Becton-Dickinson \\
& T lymphocytes & \& Co. \\
Leu 12 & B lymphocytes & Becton-Dickinson \\
& & \& Co. \\
Campath 1 & T and B lymphocytes & Hale et al. (17) \\
TG1 & Myeloid maturation & Beverly et al. (12) \\
Leu M1 & Monocytes, granulocytes & Becton-Dickinson \\
& & \& Co. \\
Leu M3 & Monocytes & Becton-Dickinson \\
& & \& Co. \\
Mo 1 & Monocytes, myeloid & Todd et al. (18) \\
& maturation, NK cells & \\
My 8 & Monocytes, myeloid & Griffin et al. (19) \\
& maturation & H. Waldmann \\
YTH 89.1.8 & Glycophorin A & Edwards (20) \\
LICR.LON.R18 & Glycophorin A & Becton-Dickinson \\
L243 & HLA-DR & \& Co. \\
& &
\end{tabular}

NK, natural killer.

cell line-conditioned medium (Mo-CM) (22) prepared from the Mo T lymphoblast cell line was kindly provided by Drs. D. Golde and J. Gasson, UCLA School of Medicine, Los Angeles, CA, and was added with GCTcell line-conditioned medium (GCT-CM) (23) (Gibco, Grand Island, NY) at $10 \%$ of the final volume ( $5 \%$ each) as a source of BPA/GM-CSF. In one experiment, highly purified recombinant GM-CSF was used instead. Either human urinary EP (Terry Fox Laboratories, Vancouver, British Columbia, Canada) at $2 \mathrm{U} / \mathrm{ml}$, or human REC obtained from transfected COS or CHO cells (5) was added to the cultures on day 0 or day 3 . The day 3 additions were made either directly to the methylcellulose cultures or, in some experiments, to cells that had been suspended in IMDM/2\% FCS with Mo/GCT CM in a tissue culture incubator at $37^{\circ} \mathrm{C} /$ $5 \% \mathrm{CO}_{2}$ for $3 \mathrm{~d}$. The total volume of these suspension cultures was 0.25 $\mathrm{ml}$, and on day $3,1 \mathrm{ml}$ of the methylcellulose culture mixture was added to the suspension cultures and the mixture plated and returned to the incubator. The final concentration of cells was $1,000-50,000$ cells $/ \mathrm{ml}$ depending on the degree of enrichment expected for the different fractions. The cells were plated in $0.5-\mathrm{ml}$ duplicates in flat-bottomed 24-well tissue culture plates (Linbro, Flow Laboratories Inc., McLean, VA) and incubated at $37^{\circ} \mathrm{C}$ in a high humidity $5 \% \mathrm{CO}_{2}, 95 \%$ air incubator. CFUE were counted on day 7 and BFU-E, CFU-GM, and CFU-MIX, comprising granulocytes and/or monocytes and erythroid cells, were counted on day 14.

Calculation of progenitor recovery. The number of colonies present in the Ficoll-Hypaque mononuclear cell fraction cultured in the presence of Mo-GCT CM was taken as $100 \%$, and recovery of progenitors in all fractions related to this by multiplying colony number in each fraction by the cumulative proportion of cells recovered after that fractionation step, i.e., recovery $=$ colony number $\times$ proportion of cells recovered $\times 100 \div$ colony number in the unfractionated sample $(+\mathrm{Mo} / \mathrm{GCT})$.

\section{Results}

Effect of sequential fractionation of human bone marrow cells on colony growth. Fig. 1 shows the recovery and enrichment 


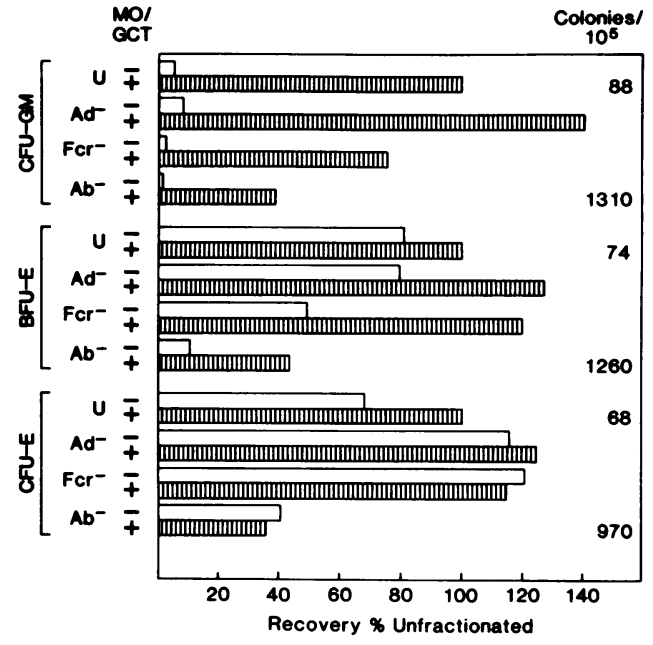

Figure 1. Fractionation of human bone marrow. $\mathrm{U}$ were sequentially fractionated by overnight adherence to plastic $\left(\mathrm{Ad}^{-}\right)$; depletion of cells with receptors for the $\mathrm{Fc}$ portion of immunoglobulin by adherence (panning) to immunoglobulin coated petri dishes ( $\mathrm{Fcr}^{-}$); and a second panning step to remove cells reacting with a panel of monoclonal antibodies recognizing maturation antigens $\left(\mathrm{Ab}^{-}\right)$. Each fraction was cultured for progenitor colony growth without (open bars) and with (hatched bars) Mo/GCT CM, and EP was added day 0 . The bar diagram indicates colony recovery as percentage of the colonies recovered in U cultured with Mo/GCT (100\%). CFU-GM (upper panel) are almost completely dependent on Mo/GCT for proliferation in all fractions. In marked contrast to CFU-E (lower panel), BFU-E show increasing Mo/GCT dependence as the fractionation proceeds. $U$ and $\mathrm{Ab}^{-}$colony number per $10^{5}$ cells plated is shown on the right of the appropriate bars.

observed in a representative experiment when Ficoll-Hypaque separated mononuclear cells $(\mathrm{U})$ were sequentially depleted of monocytes $\left(\mathrm{Ad}^{-}\right), \mathrm{Fc}$ receptor-bearing cells $\left(\mathrm{Fcr}^{-}\right)$, and maturing precursor cells $\left(\mathrm{Ab}^{-}\right)$, and each fraction was cultured in the presence or absence of Mo/GCT CM as a source of HGF. Human urinary EP was added on day 0 . Recovery for all three progenitor classes was $>70 \%$ through the first three steps, but dropped to $\sim 40 \%$ after antibody panning. CFU-GM-derived colonies show marked dependence on Mo/GCT for proliferation in culture, even in the culture of the unfractionated cell population before monocyte depletion. In contrast, CFU-E were not dependent on Mo/GCT for proliferation in this assay. A subset of BFU-E showed increasing dependence on Mo/GCT CM as monocytes, Fc receptor-bearing cells and maturing cells, including lymphocytes, were removed. Note that even the final $\mathrm{Ad}^{-} \mathrm{Fcr}^{-} \mathrm{Ab}^{-}$ fraction contained a proportion of BFU-E that were responsive to EP in the absence of Mo/GCT CM. A 14-17-fold enrichment was obtained, with $3.5 \%$ of the final fraction capable of colony formation. Representative cytospin differential counts of the cell fractions are shown in Table II. The majority of adherent cells are monocytes; Fc receptor-positive cells are mostly lymphoid cells, but include myeloid precursors and a significant number of monocytes; and antibody-positive cells comprise myeloid precursors, lymphocytes, and variable numbers of erythroid precursors and monocytes. The final $\mathrm{Ad}^{-} \mathrm{Fcr}^{-} \mathrm{Ab}^{-}$fraction is enriched for myeloblasts and large mononuclear cells with prominent nucleoli, indented or oval nuclei, and basophilic fairly abundant cytoplasm. Variable numbers of promyelocytes/myelocytes contaminate this fraction.

Enrichment of progenitors using combined negative and positive selection. Fig. 2 shows the enrichment and recovery observed when bone marrow cells were depleted of adherent cells and maturing precursors, followed by a second panning step in which adherent HLA-DR-positive cells were detached from the plastic dishes after removal of the HLA-DR-negative nonadherent cells. $60-100 \%$ of progenitors were recovered in the HLA-DR-positive fraction. Virtually all CFU-GM and BFU-E were recovered in the positive fraction in contrast to CFU-E, of which a minority $(10 \%)$ were recovered in the negative fraction. These results are similar to those previously reported using FACS analysis (24). All progenitor classes were greatly enriched, with BFU-E comprising $16 \%$, and CFU-E and CFU-GM 5.7 and $5.5 \%$ of the final fraction, respectively (39-65-fold enrichment). The enrichment observed in this and two other experiments is summarized in Table III. A similar pattern of growth dependence on Mo/GCT was observed for the three progenitor classes to that shown in Fig. 1, and even the highly enriched HLA-DR-positive fraction, plated at very low density $(1,000$ cells $/ \mathrm{ml})$ contained BFU-E responsive to EP alone (data not shown).

Effect of delaying the addition of EP on BFU-E. When EP was added to either unfractionated or highly enriched bone mar-

Table II. Cytocentrifuge Differential Counts (\%)

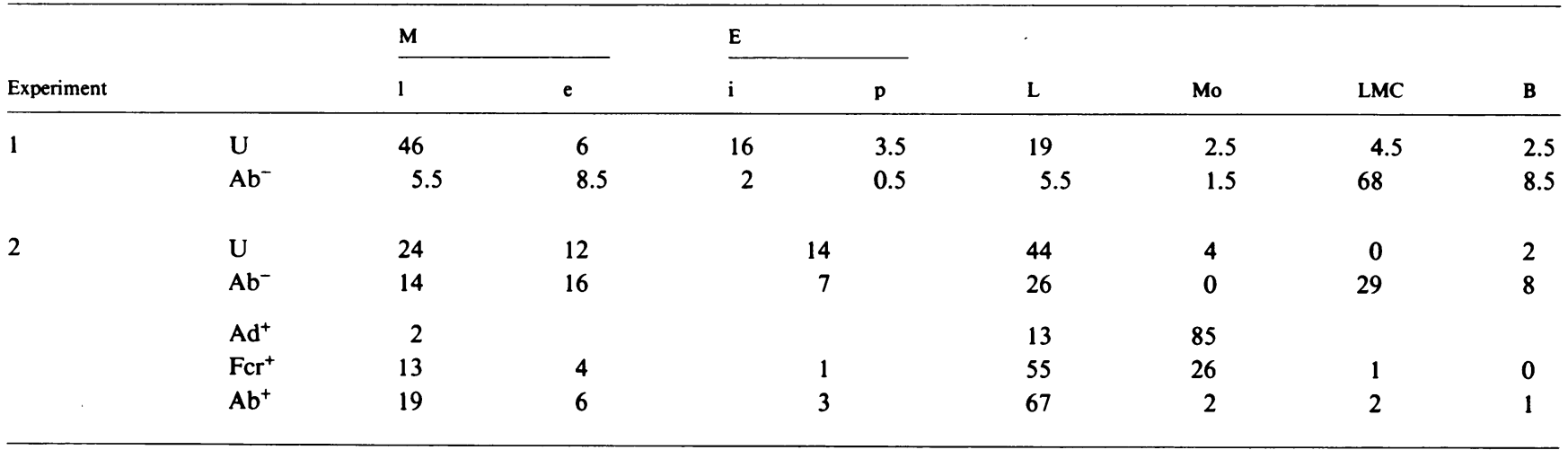

Results from two representative experiments in which 200 cells from each fraction were counted. $\mathrm{U}^{-} \mathrm{and}_{\mathrm{Ab}}^{-}$fractions were separated as indicated in Fig. $1 . \mathrm{Ad}^{+}$and $\mathrm{Fcr}^{+}$cells were removed using a rubber policeman and $\mathrm{Ab}^{+}$cells by repeated pipetting. $\mathrm{M}$, myeloid; l, late precursors-myelocytes and metamyelocytes; e, early precursors-promyelocytes; E, erythroid; i, intermediate and late normoblasts; $p$, pronormoblasts and early normoblasts; L, lymphoid; Mo, monocyte; LMC, large basophilic mononuclear cells; B, blast. 


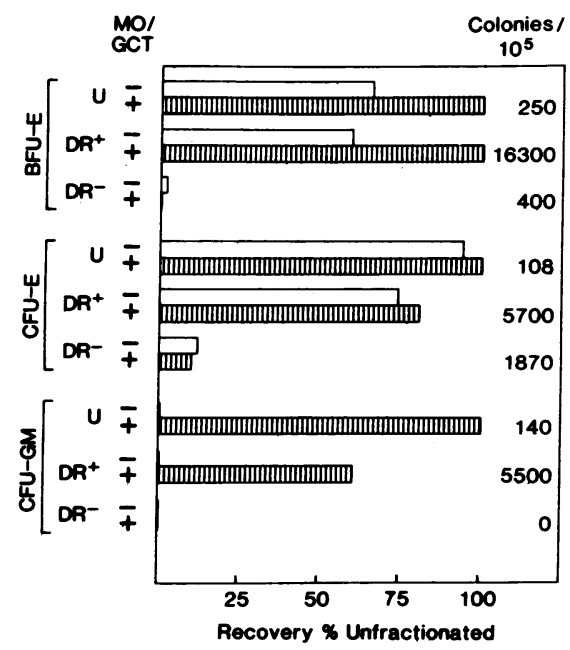

Figure 2. Enrichment of progenitors in human bone marrow. Progenitor recovery and colony growth (see Fig. 1) are shown for HLA-DR positive $\left(\mathrm{DR}^{+}\right)$and negative $\left(\mathrm{DR}^{-}\right)$cells obtained after sequential fractionation (see Methods). EP was added on day 0. 60-100\% of progenitors were recovered; virtually all the BFU-E and CFU-GM were in the DR-positive fraction, whereas a minority of CFU-E were negative. Marked enrichment was obtained, especially for BFU-E in this experiment, but note that this enriched HLA-DR ${ }^{+}$BFU-E population contained progenitors responsive to EP alone (open bar).

row BFU-E cultures on day 0 (Fig. 3, upper panel), considerable "background" BFU-E-derived colony formation was observed in both fractions. The background was unusually low for unfractionated cells in this experiment, and the results depicted in Fig. 1 are more typical. In contrast, when exposure to EP was delayed until day 3 and added either directly to the methylcellulose cultures (middle panel) or to preincubated suspension cultures, which were then plated in methylcellulose (lower panel), background colony formation in the absence of Mo/GCT CM was reduced, markedly in the highly enriched fractions. Results from the particular experiments depicted in Figs. 2 and 3 do not show increasing dependence of enriched progenitors on Mo/ GCT, as illustrated in Fig. 1. We therefore analyzed a larger series of experiments to investigate the effect of sequential depletion more thoroughly. The results for a series of 10 experiments comparing day 0 to day $3 \mathrm{EP}$ addition are summarized in Fig. 4, with the ordinate showing the ratio of BFU-E-derived colonies observed without or with Mo/GCT CM. In this series of experiments, adherent cells, Fc receptor-positive cells, and T lymphocytes (Leu $1,5 \mathrm{~b}$ positive) were sequentially removed. It is evident from Fig. 4 that unfractionated cells to which EP was added on day 0 usually showed a response to Mo/GCT. Delayed addition of EP enhances this BPA dependence in all fractions, and BFU-E in $\mathrm{Fcr}^{-}$and $\mathrm{T}$ cell-depleted fractions are almost completely dependent on exogenous BPA for proliferation in culture.

Comparison of the effect of human urinary and recombination $E P$ on enriched progenitors. It was possible that the BFU-Ederived colonies observed in the highly enriched progenitor fractions without added Mo/GCT CM were responding to BPA contaminating the partially purified human urinary EP used in these experiments. The EP gene has recently been cloned and expressed in COS cells (5). We therefore compared the effect of human urinary EP with REC on BFU-E-derived colony formation in such enriched fractions. Fig. 5 showed that both human urinary and REC added at $2 \mathrm{U} / \mathrm{ml}$ on day 0 (upper panel) stimulated similar numbers of BFU-E-derived colonies in the presence or absence of Mo-CM. Since mock COS CM has no BPA (data not shown), these data suggest that a proportion of BFU-E respond to EP alone. Both types of EP induced very low background BFU-E-derived colony formation when the addition of EP was delayed until day two (lower panel).

We therefore wished to determine whether the fraction of BFU-E that were able to respond to day 0 addition of EP alone could survive in its absence if BPA was substituted instead. Hence, we compared (Fig. 6) the number of BFU-E-derived colonies induced by day $0 \mathrm{EP}$ alone (abscissa) to the decline in colony number $(\Delta)$ observed in the presence of BPA when EP was added on day 3 compared with day 0 (ordinate). Linear regression analysis of the results of eight experiments (13 ob-

Table III. Enrichment of Progenitors Using Combined Negative and Positive Selection

\begin{tabular}{|c|c|c|c|c|c|c|c|}
\hline \multirow[b]{2}{*}{ Exp. } & \multirow[b]{2}{*}{ Cell fraction } & \multicolumn{4}{|c|}{ Derived colonies $/ 10^{5}$} & \multirow[b]{2}{*}{ CFC* } & \multirow[b]{2}{*}{ Recovery } \\
\hline & & BFU-E & CFU-E & CFU-GM & CFU-MIX & & \\
\hline & & & & & & $\%$ & $\%$ \\
\hline \multirow[t]{3}{*}{1} & $\mathrm{U}$ & 250 & 108 & 140 & ND $\ddagger$ & & \\
\hline & $\mathrm{DR}^{+}$ & 16,300 & 5,700 & 5,500 & 0 & 27.5 & $61-100$ \\
\hline & $\mathrm{DR}^{-}$ & 400 & 1,870 & 0 & 0 & & \\
\hline \multirow[t]{3}{*}{2} & $\mathbf{U}$ & 118 & 98 & 100 & 4 & & \\
\hline & $\mathrm{DR}^{+}$ & 5,000 & 2,500 & 4,200 & 100 & 11.7 & $25-43$ \\
\hline & $\mathrm{DR}^{-}$ & 200 & 1,300 & 80 & 0 & & \\
\hline \multirow[t]{3}{*}{3} & $\mathbf{U}$ & 142 & 72 & 212 & 6 & & \\
\hline & $\mathrm{DR}^{+}$ & 5,000 & 2,800 & 7,800 & 200 & 15.6 & $18-20$ \\
\hline & $\mathrm{DR}^{-}$ & 0 & 20 & 0 & 0 & & \\
\hline
\end{tabular}

Enrichment obtained for three experiments, including exp. 1, the results of which are shown in more detail in Fig. 2, in which bone marrow cells were sequentially fractionated to remove adherent cells and antibody-positive cells and then separated on the basis of HLA-DR expression.

* CFC, total colony-forming cells as a percentage of cells plated.

$¥ \mathrm{ND}$, not done. Colony density was too high in this experiment to confidently enumerate CFU-MIX. 


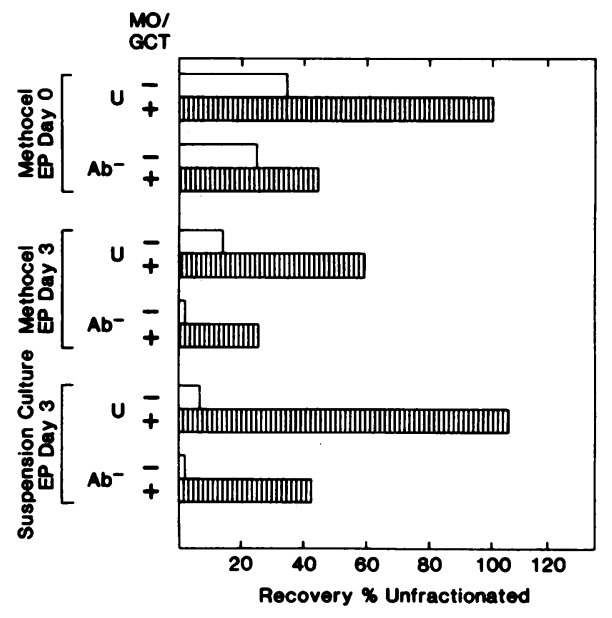

Figure 3. Effect of delayed EP addition on BFU-E derived colonies: recovery of BFU-E before $(\mathrm{U})$ and after $\left(\mathrm{Ab}^{-}\right)$sequential fractionation. When EP was added on day 0 to methylcellulose cultures (upper panel), a proportion $\left(\frac{1}{3}-\frac{1}{2}\right)$ of BFU-E-derived colonies formed in the absence of Mo/GCT (open bars). However, when EP addition to either methylcellulose cultures (middle panel) or suspension cultures (lower panel) was delayed until day 3, very few BFU-E were observed in the $\mathrm{Ab}^{-}$fraction in the absence of Mo/GCT. In this experiment, recovery in both day $3 \mathrm{EP}$ additions is related to $U+\mathrm{Mo} / \mathrm{GCT}$ day 0 EP. 176 BFU-E-derived colonies $/ 10^{5}$ cells formed in this fraction.

servations) showed a significant correlation $(r=0.88, P<0.0001$ by a two-sided $t$ test [25]) between the BFU-E-derived colony numbers for the individual experiments, whether the EP used was natural or biosynthetic, or whether EP was added on day 3 directly to methylcellulose cultures or to suspension cultures. These data suggest that the BPA-independent BFU-E population is the same subset of BFU-E that require EP from the initiation of progenitor culture. They will not survive $72 \mathrm{~h}$ in BPA alone.

$B F U-E$ dose response to $M o / G C T C M$. The dependence of a subset of highly enriched $\mathrm{Ab}^{-} \mathrm{BFU}-\mathrm{E}$ on an exogenous source of BPA when EP addition was delayed suggested that this would provide a useful assay for BPA. Pooling data from five experiments, Fig. 7 shows a normalized dose response of BFU-E to increasing concentrations of Mo-CM. A plateau was observed at $5 \% \mathrm{CM}$, and the mean maximal colony number at $10 \%$ Mo-

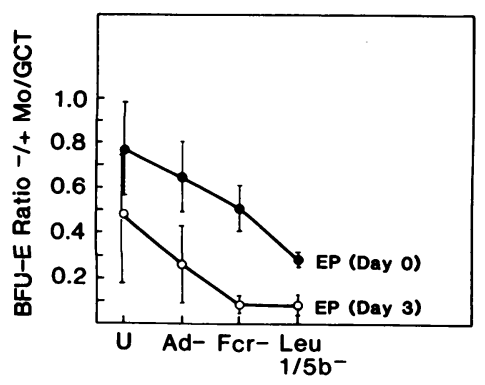

Figure 4. Summary of the effect of delayed EP addition on sequentially fractionated bone marrow. In this series of 10 experiments, the final step consisted of panning with two antibodies to $\mathrm{T}$ lymphocytes (Leu 1/5b), and the graph shows the ratio of BFU-E-derived colonies observed without or with Mo/GCT for each fraction when EP was added on either day 0 (solid circles) or day 3 (open circles). In all fractions, delay of the addition of EP increased dependence on Mo/GCT and the day 3 addition $\mathrm{Fcr}^{-}$ and Leu $1 / 5 b^{-}$fractions were almost totally dependent on Mo/GCT for proliferation (ratio $<0.1$ ). Colony number per $10^{5} \mathrm{U}$ ranged from 17 to $142 \mathrm{BFU}-\mathrm{E} / 10^{5}$ and recovery from 40 to $122 \%$.

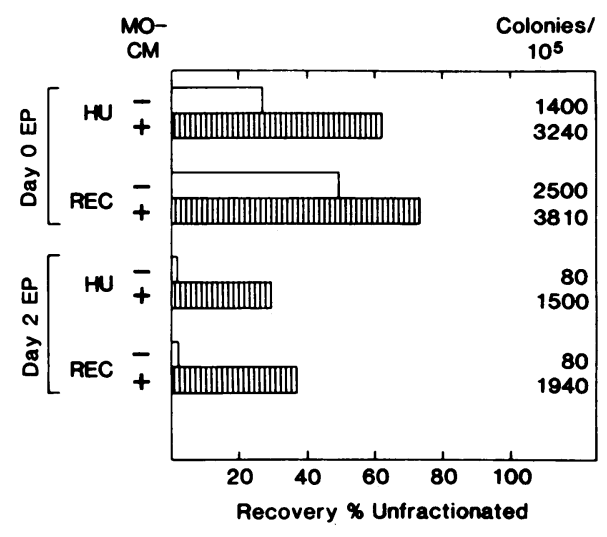

Figure 5. Comparison of the effect of human urinary (Terry Fox Laboratories) and REC on $\mathrm{Ab}^{-}$-enriched BFU-E. The histogram shows recovery of enriched $\mathrm{Ab}^{-}$bone marrow BFU-E in relation to $\mathrm{U}+$ MoCM taken as $100 \%$ (not shown). BFU-E-derived colony number in this control fraction was $120 / 10^{5}$. Both sources of EP stimulated similar numbers of BFU-E-derived colonies in the presence or absence of Mo-CM, and very few colonies were observed in the absence of MoCM when EP addition was delayed until day 2 (open bars). CM from mock transfected COS cells had no EP or BPA activity.

$\mathrm{CM}$ was $1,415 \mathrm{BFU}-\mathrm{E} / 10^{5} \mathrm{Ab}^{-} \mathrm{BM}$ cells (range 320-1,970). Background colony formation was very low in the absence of Mo-CM (mean 75, range 13-180 BFU-E/ $10^{5}$ cells).

Effect of increasing REC concentration on CFU-GM-derived colonies. In view of the hypothesis that EP can act as an instructive molecule and promote stem cell or bipotent progenitor commitment to erythropoiesis at the expense of other haemopoietic lineages, we carried out a dose response on highly enriched progenitors using REC (Fig. 8). We have recently shown that recombinant GM-CSF has BPA (6), and we used highly purified (specific activity $1-4 \times 10^{7} \mathrm{U} / \mathrm{mg}$ in an agar bone marrow CFUGM assay [1]) recombinant GM-CSF as the source of BPA for this experiment to define the culture conditions as carefully as possible. The result showed no inhibitory effect of increasing

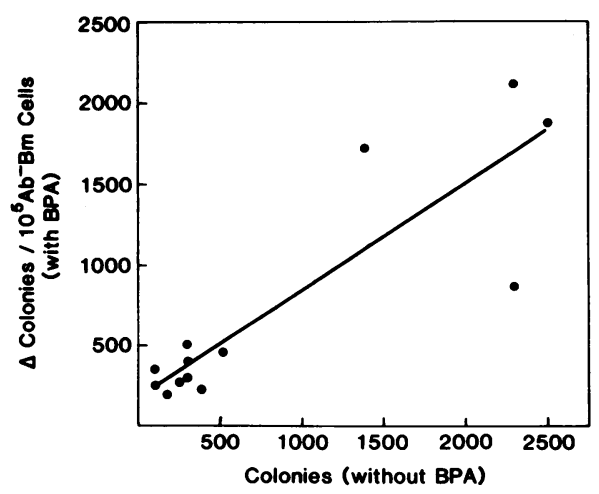

Figure 6. Relationship of EP to BPA requirement of a subset of BFUE. The ordinate represents the difference $(\Delta)$ between the frequencies of BFU-E-derived colonies that appear in the presence of BPA when EP is added either on day 0 or day 3 to duplicate cultures of a BM progenitor concentrate. The abscissa represents the colonies that appear in the same cultures in the absence of BPA when EP is added on day 0 . Linear regression analysis reveals a close correlation $(r=0.88$, $P<0.0001$ by a two-sided $t$ test). 


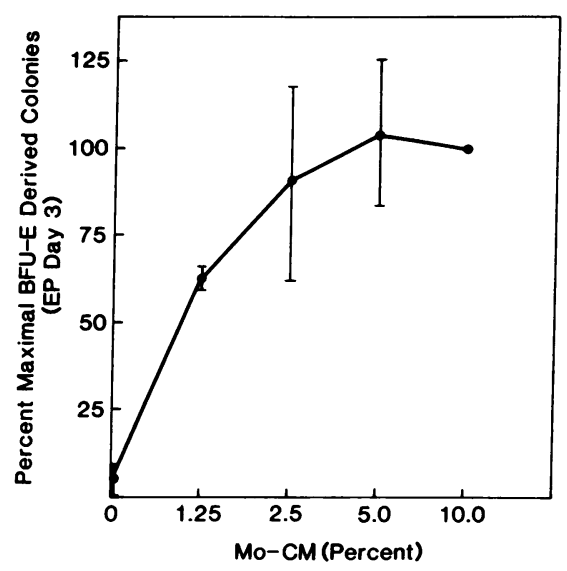

Figure 7. Normalized Mo-CM dose responses of enriched $\left(\mathrm{Ab}^{-}\right)$bone marrow BFU-E after delayed addition of EP. Data were pooled from five experiments and shows mean $\pm 1 \mathrm{SD}$. There are very few BFU-Ederived colonies (mean 75 , range $13-180 / 10^{5}$ cells) in the absence of Mo-CM and a plateau was observed at 5\% Mo-CM. The maximal BFU-E number at $10 \%$ Mo-CM was 1,415 (range $320-1,970$ )/10 cells.

doses of erythropoietin on CFU-GM-derived colony numbers. At very high doses, the REC is apparently inhibitory, but this may have been due to the larger volume necessary to incorporate this dose in the cultures, or to other inhibitory components present in the EP preparation.

\section{Discussion}

In this report, we demonstrate that normal human bone marrow cells can be sequentially depleted of BPA-producing accessory cells to provide a final nonadherent, $\mathrm{Fc}$ receptor and multiple antibody-negative cell fraction that is considerably enriched for progenitors. A second positive selection panning step using an antibody to HLA-DR antigens results in further enrichment, with total colony-forming cells comprising $12-27 \%$ of this fraction, and progenitor and cell recovery, $19-100 \%$ and $0.5-1 \%$, respectively. To our knowledge, this is the highest concentration of a workable population of normal human bone marrow progenitors achieved to date.

Previous attempts to enrich for progenitors in bone marrow have been beset with difficulties relating mainly to progenitor yield. Thus, although the FACS can be used in conjunction with

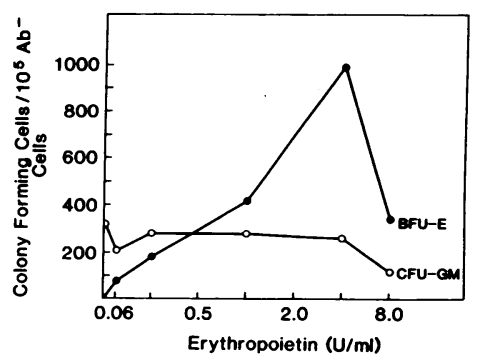

Figure 8. Dose response of enriched bone marrow progenitors to REC. Although a progressive linear BFU-E response was observed from 0.63 to $4.0 \mathrm{U} / \mathrm{ml}$, CFUGM-derived colony numbers remained constant over this range. Cultures contained $1 \mathrm{ng} / \mathrm{ml}$ recombinant GM-CSF (maximal stimulation for this material) and $5 \times 10^{3} \mathrm{Ab}^{-}$bone marrow cells $/ \mathrm{ml}$. EP was added on day 0 . monoclonal antibodies to select positively for progenitors (11, 12), impractically prolonged sorting times are necessary to select rare cells, and yields are often reduced (20-50\%). Complement lysis is associated with significant nonspecific cell loss (13), and normal bone marrow progenitors may be sensitive to nonspecific damage by $\mathrm{CrCl}_{3}$-coupled erythrocytes that are used for immune rosetting. Immunoadsorption to antibody-coated plates (panning) can be used for negative and positive selection (21), and is a simple, reproducible procedure that can provide highly enriched progenitor fractions, with moderately reduced yields. In this respect, our results are not as good as those we obtained when separating human fetal liver progenitors (yields $60-100 \%$ ) (16), but fetal liver cells are two- to fivefold enriched for progenitors compared with bone marrow, and do not require such extensive fractionation. The results do, however, compare very favorably with other attempts to enrich human bone marrow progenitors $(12,14,26)$.

The sequential fractionation data demonstrate that the majority of bone marrow BFU-E require a source of exogenous BPA for their survival in vitro. In unfractionated marrow, the BPA requirement for these BFU-E is partially met by adherent cells, $\mathrm{Fcr}^{+}$cells, and $\mathrm{T}$ lymphocytes. The increasing dependence of this subset of BFU-E in sequentially fractionated bone marrow cells on an exogenous source of BPA supports previous evidence and recent data from this laboratory (14) that bone marrow monocytes (14, 27-29), Fc receptor-bearing cells (14), and T lymphocytes $(14,29-32)$ produce BPA or collaborate in its production. However, even highly enriched progenitor fractions contain a fraction of BFU-E responsive to EP in the absence of BPA and unaffected by accessory cell depletion. That this BFUE population is responsive to EP and not a BPA contaminant in human urinary EP is shown by the similar results obtained when REC was used. Furthermore, the number of day 0 EPresponsive BFU-E-derived colonies correlates significantly with the decline in BFU-E observed when the addition of EP is delayed until day 3 in the presence of Mo/GCT CM. This suggests that once BFU-E have become EP sensitive, they require exposure to the hormone for survival and terminal differentiation. They appear to die or become unresponsive in its absence. Thus, although most BFU-E survive in the presence of BPA for $3 \mathrm{~d}$, a smaller proportion are BPA independent and require exposure to EP for terminal differentiation to occur. We presume that the former represent immature, and the latter, mature, BFU-E. The results support previous evidence suggesting that BFU-E are heterogeneous with respect to their BPA and EP responsiveness $(33,34)$, and are consistent with recent short-term bone marrow liquid culture results suggesting that day 15 BFU-E are sensitive to EP (35).

The EP responsive BPA-independent BFU-E population has made it difficult to assay for BPA in the past, since EP is essential for terminal maturation of all erythroid colonies. When EP is added to cultures on day 0 , the result is a high background of BPA-independent BFU-E-derived colonies that are indistinguishable from the BFU-E-derived colonies forming in the presence of BPA. However, if accessory cell-depleted progenitors are used as target cells, the simple maneuver of delaying the addition of EP until day 3 can obviate this problem by eliminating BFU$E$ responsive to $\mathrm{EP}$ alone. A subset of (presumably) less mature BFU-E then show a typical dose response to increasing concentrations of Mo/GCT CM, and provide a sensitive BFU-E population for BPA assay. We have recently used this assay to show 
that highly purified recombinant GM-CSF, cloned from the Mo cell line, has significant BPA (6).

The availability of recombinant GM-CSF and EP, and enriched progenitors, has made it possible to reexamine the question of whether EP can act as an instructive molecule and influence progenitor commitment toward erythropoiesis at the expense of granulopoiesis, as suggested by van Zant and Goldwasser $(36,37)$. Our results do not support this view, since the frequency of CFU-GM-derived colonies was constant despite a wide variation in EP concentration and resultant erythroid colonies.

In conclusion, the ability to obtain highly enriched human bone marrow progenitors using a relatively simple method will be valuable for investigating the regulation of hemopoiesis at a cellular level. This will be particularly relevant as more highly purified and recombinant human growth factors become available. The ability to assay more accurately for BPA, and for BPA and erythropoietin-responsive progenitors, should allow an improved evaluation of these parameters in hypoplastic anemias and myeloproliferative disorders, and thereby offer opportunities to gain further insight into their pathophysiology and effective treatment.

\section{Acknowledgments}

We thank Elizabeth Wong for providing purified recombinant GM-CSF, Jane Aghajanin for assaying the REC, and Carolyn Gregory for preparing the manuscript. YTH 89.1.8 was kindly provided by Dr. H. Waldmann, Cambridge University, United Kingdom.

This paper was supported by grants from the National Institutes of Health and by the Dyson Foundation.

\section{References}

1. Wong, G. G., J. S. Witek, P. A. Temple, K. M. Wilkens, A. C. Leary, D. P. Luxenberg, S. S. Jones, E. L. Brown, R. M. Kay, E. C. Orr, C. Shoemaker, D. W. Golde, R. J. Kaufman, R. M. Hewick, E. A. Wang, and S. C. Clark. 1985. Human GM-CSF: molecular cloning of the cDNA and purification of the natural and recombinant proteins. Science (Wash. DC). 228:810-815.

2. Westbrook, C. A., J. C. Gasson, S. E. Gerber, M. E. Selsted, and D. W. Golde. 1984. Purification and characterization of human T-lymphocyte-derived erythroid potentiating activity. J. Biol. Chem. 259:99929996.

3. Gasson, J. C., D. W. Golde, S. E. Kaufman, C. A. Westbrook, R. M. Hewick, R. J. Kaufman, G. G. Wong, P. A. Temple, N. C. Leary, E. L. Brown, E. C. Orr, and S. C. Clark. 1985. Molecular characterization and expression of the gene encoding human erythroid potentiating activity. Nature (Lond.). 315:768-771.

4. Miyake, T., C. K.-H. Kung, and E. Goldwasser. 1977. Purification of human erythropoietin. J. Biol. Chem. 252:5558-5564.

5. Jacobs, K., C. Shoemaker, R. Rudersdorf, S. D. Neill, R. J. Kaufman, A. Mufson, J. Seehra, S. S. Jones, R. Hewick, E. F. Fritsch, M. Kawakita, T. Shimizu, and T. Miyake. 1985. Isolation and characterization of genomic and cDNA clones of human erythropoietin. Nature (Lond.). 313:806-810.

6. Sieff, C. A., S. G. Emerson, R. E. Donahue, E. A. Wang, G. G. Wong, S. C. Clark, and D. G. Nathan. 1985. Human recombinant granulocyte-macrophage colony stimulating factor has burst promoting activity. Science (Wash. DC). 230:1171-1174.

7. Worton, R. G., E. A. McCulloch, and J. E. Till. 1969. Physical separation of haemopoietic stem cells from cells forming colonies in culture. J. Cell. Physiol. 74:171-182.

8. Moore, M. A. S., N. Williams, and D. Metcalf. 1972. Purification and characterization of the in vitro colony forming cell in monkey hemopoietic tissue. J. Cell. Physiol. 79:283-292.
9. Nijhof, W., and P. K. Wierenga. 1984. Isolation and characterization of the erythroid progenitor cell: CFU-E. J. Cell Biol. 96:386392.

10. Nicola, N. A., D. Metcalf, H. Von Melchner, and A. W. Burgess. 1981. Isolation of murine hemopoietic progenitor cells and selective fractionation of various erythroid precursors. Blood. 58:376-386.

11. Morstyn, G., N. A. Nicola, and D. Metcalf. 1980. Purification of hemopoietic progenitor cells from human marrow using a fucosebinding lectin and cell sorting. Blood. 56:798-805.

12. Beverley, P. C. L., D. Linch, and D. Delia. 1980. Isolation of human haematopoietic progenitor cells using monoclonal antibodies. Nature (Lond.). 287:332-333.

13. Sieff, C., G. Caine, P. Goodfellow, P. W. Andrews, L. Davies, and $M$. Greaves. Cell surface antigens expressed on haemopoietic stem cells: use of monoclonal antibodies to enrich for multipotent and committed progenitors. Blood. Submitted for publication.

14. Linch, D. C., J. M. Lipton, and D. G. Nathan. 1985. Identification of three accessory cell populations in human bone marrow with erythroid burst-promoting properties. J. Clin. Invest. 75:1278-1284.

15. Hoang, T., D. Gilmore, D. Metcalf, S. Cobbold, S. Watt, M. Clark, M. Furth, and H. Waldmann. 1983. Separation of hemopoietic cells from adult mouse marrow by use of monoclonal antibodies. Blood. 61:580-588.

16. Emerson, S. G., C. A. Sieff, E. A. Wang, G. G. Wong, S. C. Clark, and D. G. Nathan. 1985. Purification of hemopoietic progenitors and demonstration of recombinant multipotential colony stimulating activity. J. Clin. Invest. 76:1286-1290.

17. Hale, G., S. Bright, G. Chumbley, T. Hoang, D. Metcalf, A. J. Munro, and H. Waldmann. 1983. Removal of T cells from bone marrow for transplantation: a monoclonal antilymphocyte antibody which fixes human complement. Blood. 62:873-882.

18. Todd, R. F., L. M. Nadler, and S. F. Schlossman. 1981. Antigens on human monocytes identified by monoclonal antibodies. J. Immunol. 126:1435-1442.

19. Griffin, J. D., J. Ritz, L. M. Nadler, and S. F. Schlossman. 1981. Expression of myeloid differentiation antigens on normal and malignant cells. J. Clin. Invest. 68:932-941.

20. Edwards, P. A. W. 1980. Monoclonal antibodies that bind to the human erythrocyte-membrane glycoproteins glycophorin A and Band 3. Biochem. Soc. Trans. 8:334-335.

21. Wysocki, L. J., and V. L. Sato. 1978. "Panning" for lymphocytes: a method for cell selection. Proc. Natl. Acad. Sci. USA. 75:2844-2848.

22. Golde, D. W., N. Bersch, S. G. Quan, and A. J. Lusis. 1980. Production of erythroid-potentiating activity by a human T-lymphoblast cell line. Proc. Natl. Acad. Sci. USA. 77:593-596.

23. DiPersio, J. F., J. K. Brennan, M. A. Lichtman, C. N. Abboud, and F. H. Kirkpatrick. 1980. The fractionation, characterization, and subcellular localization of colony-stimulating activities released by the human monocyte-like cell line GCT. Blood. 56:717-727.

24. Robinson, J., C. Sieff, D. Delia. P. A. W. Edwards, and M. Greaves. 1981. Expression of cell surface HLA-DR HLA-ABC and glycophorin during erythroid differentiation. Nature (Lond.). 289:68-71.

25. Snedicor, G. W., and W. G. Cochran. 1973. Statistical Methods. Iowa State Univ. Press, Ames. Sixth ed.

26. Greenberg, P. L., S. Baker, M. Link, and J. Minowada. 1985. Immunologic selection of hemopoietic precursor cells utilizing antibodymediated plate binding ("panning"). Blood. 65:190-197.

27. Gordon, L. I., W. J. Miller, R. F. Branda, E. D. Zanjani, and H. S. Jacob. 1980. Regulation of erythroid colony formation by bone marrow (BM) macrophages. Blood. 55:1047-1050.

28. Zuckerman, K. S. 1981. Human erythroid burst-promoting units growth in vitro is dependent on monocytes but not $\mathrm{T}$ lymphocytes. J. Clin. Invest. 67:702-709.

29. Reid, C. P. L., L. C. Baptista, and I. Chanarin. 1981. Erythroid colony growth in vitro from human peripheral blood null cells: evidence for regulation by $\mathrm{T}$ lymphocytes and monocytes. Br. J. Haematol. 48:155-164. 
30. Mangan, K. F., G. Chikkappa, L. Z. Sieler, W. B. Scharfman, and D. R. Parkingson. 1982. Regulation of human blood erythroid burstforming unit (BFU-E) proliferation by $\mathrm{T}$ lymphocyte subpopulations defined by Fc receptors and monoclonal antibodies. Blood. 59:990-996.

31. Nathan, D. G., L. Chess, D. G. Hillman, B. Clarke, J. Breard, E. Merler, and D. E. Housman. 1978. Human erythroid burst-forming unit: T cell requirement for proliferation in vitro. J. Exp. Med. 147: 324-339.

32. Torok-Storb, B., P. J. Martin, and J. A. Hansen. 1981. Regulation of in vitro erythropoiesis by normal $\mathrm{T}$ cells: evidence for two $\mathrm{T}$ cell subsets with opposing function. Blood. 58:171-174.

33. Eaves, C. J., and A. C. Eaves. 1978. Erythropoietin dose-response curves for three classes of erythroid progenitors in normal human marrow and in patients with polycythaemia vera. Blood. 52:1196-1210.
34. Lipton, J. M., M. Kudisch, and D. G. Nathan. 1981. Response of three classes of human erythroid progenitors to the absence of erythropoietin in vitro as a measure of progenitor maturity. Exp. Hematol. 9:1035-1041.

35. Dessypris, E. N., and S. B. Krantz. 1984. Effect of pure erythropoietin on DNA synthesis by human marrow day 15 erythroid burst forming units in short-term liquid culture. Br. J. Haematol. 56:295-306.

36. Van Zant, G., and E. Goldwasser. 1979. Competition between erythropoietin and colony stimulating factor for target cells in mouse bone marrow. Blood. 53:946-965.

37. Van Zant, G., and E. Goldwasser. 1977. The simultaneous effects of erythropoietin and colony stimulating factor on bone marrow cells. Science. (Wash. DC). 198:733-735. 